\title{
DISCHARGE COEFFICIENT OF BROAD-CRESTED WEIRS AS A FUNCTION OF THE RELATIVE WEIR HEIGHT FOR DIFFERENT WEIR LENGTHS
}

\author{
Lviv Polytechnic National University, Lviv, Ukraine, \\ Department of Hydraulic and Water Engineering, \\ volodymyr.m.zhuk@lpnu.ua
}

(C) Zhuk V., Matlai I., Popadiuk I., Vovk L., Rehush V., 2020

Broad-crested weirs $(\mathrm{BCW})$ are often used in hydraulic engineering and water management. The most complex factor that affects the discharge capacity of $\mathrm{BCW}$ is the discharge coefficient. In Ukrainian engineering practice, the flow rate of $\mathrm{BCW}$ is defined as a function of the relative height of the spillway wall, while in the most common European methods - as a function of the relative length of the weir. The experimental dependences of the discharge coefficient of rectangular sharp-edged $\mathrm{BCW}$ with vertical inlet and outlet walls with the ratio of the weir length and height $\delta / P=2 ; 4$ are obtained. A comparison of the obtained results with the values of the discharge coefficient of the same $\mathrm{BCW}$ using the methods of Kumin and Hager indicates that this coefficient depends on both the height of the wall and the length of the weir. The corresponding empirical power law dependences are obtained. At the same values of the relative height of the wall, the discharge coefficient for the weir with the ratio $\delta / P=4$ is significantly lower comparing the weir with $\delta / P=2$, that can be explained by the more significant effect of friction resistance for the weir with longer threshold.

Key words: broad-crested weir, discharge coefficient, relative height of the wall, relative length of the weir.

\section{Introduction}

Broad-crested weirs $(\mathrm{BCW})$ are simple hydraulic structures that are often used in hydraulic engineering, on water intake and spillway structures, including the inlet and outlet devices of the stormwater management structures. The advantages of using BCW include simplicity of construction and economy of installation, high strength and long period of operation, low sensitivity of the discharge coefficient to the conditions of the surcharge. In some cases, $\mathrm{BCW}$ is a convenient tool for measuring the volumetric flow rate of water in open channels (Badr \& Mowla, 2014; Zhuk et al., 2020).

The most complex factor that affects the discharge capacity of $\mathrm{BCW}$ is the discharge coefficient. The literature review indicates that the methods for the estimation of the BCW discharge coefficient are generally based on two main approaches. According to the "Recommendations on the hydraulic calculation of weirs P 18-74", that is in force in Ukraine, the discharge coefficient of BCW is considered only as a function of the relative height of the weir upstream wall (Konstantinov \& Hizha, 2006; Rekomendatsii, 1974; Bolshakov, 1984). On the other hand, most European countries use a different approach, which is based on the assumption that the BCW discharge coefficient depends only on the relative length of the threshold and is not a function of wall height (Hager \& Schwalt, 1994; Govinda Rao \& Muralidhar, 1963; Jalil et al., 2014; Salmasi et al., 2011; Guven et al., 2013; Kulkarni et al., 2020; Zachoval et al. 2014).

Review of scientific papers shows that there are still a number of questions about the reliability of determining the discharge coefficient for BCW with different weir length to height ratios (Azimi et al., 
2013; Bolshakov, 1984; Govinda Rao \& Muralidhar, 1963; Hager \& Schwalt, 1994; Konstantinov \& Hizha, 2006; Rekomendatsyy, 1974; Rohalevych, 2010).

\section{The purpose of the work}

Obtaining and analysis of experimental dependences of the discharge coefficient of rectangular sharp-edged BCW with vertical inlet and outlet walls for the different weir length to height ratios.

\section{The results of previous studies}

Depending on the relative length, the ratio of the weir length and height $\delta / P$, of the threshold, there are sharp-crested, finite-crested and broad-crested weirs, however, the numerical criteria for the weirs of different types slightly vary (Table 1$)$.

Table 1

Relative length of the weir threshold $\delta / H$ for the different types of weirs

\begin{tabular}{|c|l|c|c|c|c|c|}
\hline \multirow{2}{*}{$\#$} & \multirow{2}{*}{ Type of the weir } & \multicolumn{5}{|c|}{ Range $\delta / H$ according to: } \\
\cline { 3 - 7 } & & $\begin{array}{c}\text { Bolshakov, } \\
1984\end{array}$ & $\begin{array}{c}\text { Recom. } \\
\mathrm{P} 18-74\end{array}$ & $\begin{array}{c}\text { Azimi et al., } \\
2013\end{array}$ & Sturm, 2001 & $\begin{array}{c}\text { Hager \& Schwalt, } \\
1994\end{array}$ \\
\hline 1 & Sharp-crested weir & $<0.67$ & $\leq 0.5$ & $<0.5$ & $<0.67$ & $<0.67$ \\
\hline 2 & Finite-crested weir & $0.67-(2 \div 3)$ & $0.5-2$ & $0.5-2.5$ & $0.67-3.03$ & $0.67-2.5$ \\
\hline 3 & Broad-crested weir & $(2 \div 3)-(8 \div 10)$ & $2-8$ & $2.5-10$ & $3.03-12.5$ & $2.5-10$ \\
\hline
\end{tabular}

Volumetric flow rate of rectangular sharp-edged BCW according to (Azimi et al., 2013; Bolshakov, 1984; Govinda Rao \& Muralidhar, 1963; Hager \& Schwalt, 1994; Konstantinov \& Hizha, 2006; Rohalevych, 2010):

$$
Q=m b \sqrt{2 g} H_{0}^{3 / 2},
$$

where $m$ - the discharge coefficient of rectangular sharp-edged BCW; $b$ - width of the weir; $H_{0}-$ total head on the weir, which is found as a sum of geometric and velocity heads (Azimi et al., 2013; Bolshakov, 1984; Govinda Rao \& Muralidhar, 1963; Hager \& Schwalt, 1994; Konstantinov \& Hizha, 2006; Rekomendatsii, 1974; Rohalevych, 2010):

$$
H_{0}=H+\frac{\alpha V^{2}}{2 g},
$$

where $H$ - geometric head of weir; $\alpha$ - kinetic energy factor, $\alpha=1-1.1 ; V$ - average velocity on the upstream side of the weir:

$$
V=\frac{Q}{b(P+H)},
$$

where $P$ - the height on the upstream side of the weir.

According to the empirical data of Kumin (Rekomendatsii, 1974; Bolshakov, 1984) the discharge of rectangular sharp-edged $\mathrm{BCW}$ with vertical inlet and outlet walls depends on the relative height of the threshold $P / H$ (Table 2).

Table 2

The discharge coefficient $m$ of BCW as a function of the relative height of the threshold $P / H$ according to Kumin (Rekomendatsii, 1974; Bolshakov, 1984)

\begin{tabular}{|c|c|c|c|c|c|c|c|c|c|c|}
\hline$P / H$ & 0 & 0.2 & 0.4 & 0.6 & 0.8 & 1 & 2 & 4 & 8 & $\infty$ \\
\hline$m$ & 0.385 & 0.366 & 0.356 & 0.35 & 0.345 & 0.342 & 0.333 & 0.327 & 0.324 & 0.32 \\
\hline
\end{tabular}


An approximation dependence with a coefficient of determination $\mathrm{R}^{2}=0.9984$ was obtained after processing of the data given in the Table 2 :

$$
m=0.32+\frac{1}{29.65 P / H+16.60} .
$$

The maximum deviation of the calculated values of the discharge coefficient obtained by equation (4) from the results given in Table 2, does not exceed $0.5 \%$ in the range of values of the relative height of the weir $P / H \geq 0.2$ (Fig. 1).

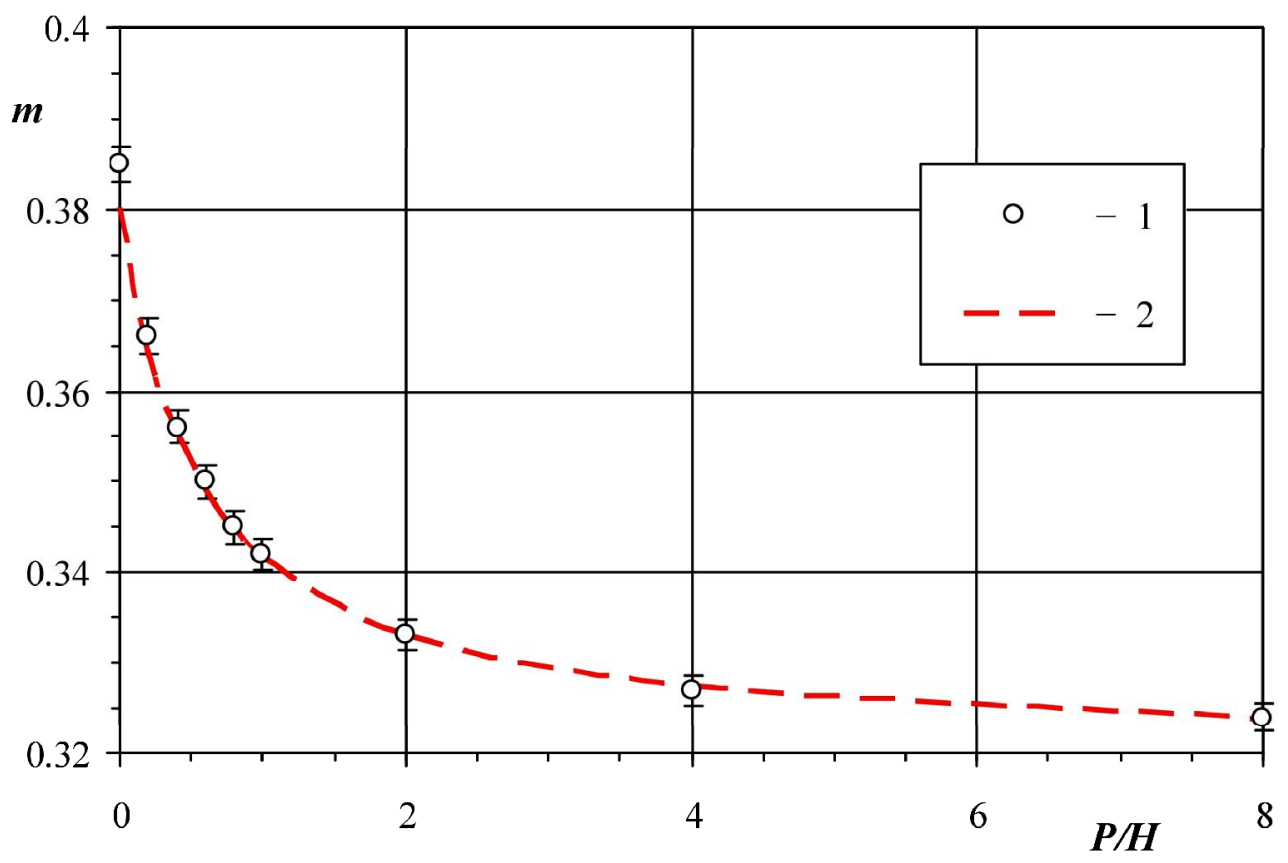

Fig. 1. The discharge coefficient of broad-crested weirs:

1- empirical data of Kumin (Rekomendatsii, 1974; Bolshakov, 1984);

2 - calculated values according to formula (4) (series indicate the levels of relative error $\pm 0.5 \%$ )

According to another approach, the discharge coefficient of BCW depends only on the relative length of the weir (Hager \& Schwalt, 1994; Govinda Rao \& Muralidhar, 1963). For example, W. Hager obtained theoretically substantiated dependence recommended for heads $H_{0}$ more than $0.03-0.05 \mathrm{~m}$ (Hager \& Schwalt, 1994):

$$
m=0,326 \times \frac{9}{7} \times\left(1-\frac{2 / 9}{1+\left(H_{0} / \delta\right)^{4}}\right) .
$$

A simple comparison of the Kumin and Hager methods for the same $\mathrm{BCW}$ indicates a significant difference in the corresponding values of the discharge coefficient. It is logical to assume that the discharge coefficient depends on both the height of the wall and the length of the weir, by analogy with two components of hydrodynamic resistance - local resistance and friction resistance. The values of the discharge coefficient of BCW using the above mentioned approaches (Kumin's empirical data recommended by (Rekomendatsii, 1974) and theoretically substantiated method of W. Hager (Hager \& Schwalt, 1994)) with the experimental results, obtained by the authors, are compared below.

\section{Materials and methods}

In the hydraulic laboratory of the Department of Hydraulic and Water Engineering of the Lviv Polytechnic National University a series of experimental studies to determine the discharge coefficient of rectangular sharp-edged $\mathrm{BCW}$ in the range $\delta / P=(2-4)$. The investigated $\mathrm{BCW}$ with a height of threshold 
$P=5 \mathrm{~cm}$ and a length $\delta=10-20 \mathrm{~cm}$ was installed in a hydraulic channel with a width of $b=22.4 \mathrm{~cm}$. Flow rate $Q, \mathrm{~m}^{3} / \mathrm{s}$, was determined using a standard V-notch measuring weir and calculated by King's formula (Rekomendatsii, 1974; Bolshakov, 1984):

where $H_{m}$ is the head on the measuring weir, $\mathrm{m}$.

$$
Q=1.343 H_{m}{ }^{2.47},
$$

The V-notch measuring weir was calibrated by the volumetric method, standard error compared to the results of King's formula is $\sigma=0.018$.

Experimental values of the discharge coefficient of $\mathrm{BCW}$ were found from the formula

$$
m=\frac{Q}{b \sqrt{2 g} H_{0}^{3 / 2}},
$$

where $H_{0}$ - total head on the weir, calculated by formulas (2)-(3); the value of the kinetic energy factor is taken as constant and equal to $\alpha=1.05$.

The maximum relative errors in the experimental determination of the discharge coefficient of $\mathrm{BCW}$ were equal $1.0-3.2 \%$ depending on the value of the geometric head on the weir.

The results of an experimental study of two BCW with height of weir $5 \mathrm{~cm}$ and a length of weir $\delta_{1}=10 \mathrm{~cm}$ and $\delta_{2}=20 \mathrm{~cm}$, which correspond to the limit range for $\mathrm{BCW} \delta / H=(2-10)$, are presented below.

The investigated ranges of the main input parameters for BCW with a length of weir $\delta_{1}=10 \mathrm{~cm}$ and $\delta_{2}=20 \mathrm{~cm}$ were respectively: flow discharge $Q_{1}=(0.91-3.60) \mathrm{l} / \mathrm{s}, Q_{2}=(0.34-4.00) \mathrm{l} / \mathrm{s}$; head on the weir $H_{1}=(1.99-4.74) \mathrm{cm}, H_{2}=(1.01-5.01) \mathrm{cm}$; total energy head on the weir $H_{0.1}=$ $=(2.01-4.89) \mathrm{cm} ; H_{0.2}=(1.01-5.18) \mathrm{cm}$.

Obtained results are presented as graphical dependencies of the discharge coefficient $m$ on the relative height of the weir $P / H$ (Fig. 2). To be able to compare the discharge coefficient $m$ by different methods, it was recalculated using the Hager method (Hager \& Schwalt, 1994) using formula (5) with the transition from the relative length of the weir $\delta / H$ to the parameter $P / H$.

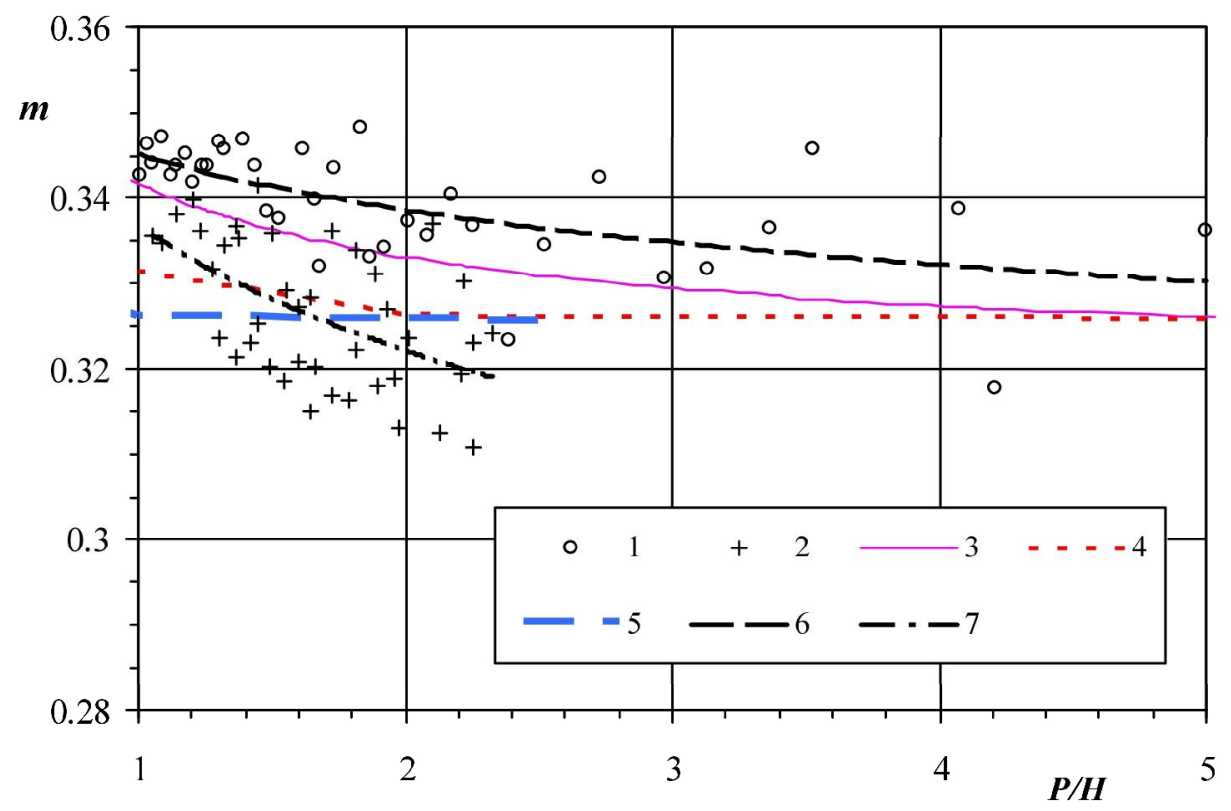

Fig. 2. Dependencies of the discharge coefficient of $B C W$ on the relative height of the weir P/H: 1, 2-experimental data obtained for the length of the weir $10 \mathrm{~cm}$ and $20 \mathrm{~cm}$, respectively; 3 - according to Kumin's data (Rekomendatsii, 1974; Bolshakov, 1984); 4, 5 - according to Hager's data for the length of the weir $10 \mathrm{~cm}$ and $20 \mathrm{~cm}$, respectively (Hager \& Schwalt, 1994); 6, 7 - power law trends describing the experimental data for the length of the weir $10 \mathrm{~cm}$ (8) and $20 \mathrm{~cm}$ (9), respectively 
The obtained experimental results are well described by power law functions. For the length of the weir $\delta=10 \mathrm{~cm}(\delta / P=2)$ it is obtained:

$$
m=0.345 \cdot(P / H)^{-0.0275},
$$

and for the $\mathrm{BCW}$ with the length of the weir $\delta=20 \mathrm{~cm}(\delta / P=4)$ :

$$
m=0.337 \cdot(P / H)^{-0.0646} \text {. }
$$

Experimental results, obtained during the research, confirm that the discharge coefficient of BCW depends on both the height and the length of the weir, which can be seen from comparing $m$ values for weirs with different length at the same $P / H$ values (Fig. 2). In the entire investigated range, the discharge coefficient for the weir with the length of $\delta=20 \mathrm{~cm}$ at the same $P / H$ is significantly less than for the weir with the length of $\delta=10 \mathrm{~cm}$, which can be explained by the big influence of the frictional resistance for the weir with a larger length.

Comparison of the experimental results for rectangular sharp-edged BCW with vertical inlet and outlet walls with the corresponding values received according to Kumin's data and by the Hager's method, shows that the discharge coefficient of the experimental BCW with the length of $\delta=10 \mathrm{~cm}($ at $\delta / P=2)$ is $1.0-1.7 \%$ higher than the corresponding values for Kumin's $m_{K}$ and 1.4-4.1\% higher comparing the Hager's value $m_{H}$ (Table 3$)$. On the other hand, for BCW with the length of $\delta=20 \mathrm{~cm}($ at $\delta / P=4)$ different tendencies were obtained: the experimental discharge coefficient of investigated BCW is less up to $4.1 \%$ than the corresponding values of $m_{K}$, while the relative difference with $m_{H}$ varies from $-2.6 \%$ to $6.3 \%$ depending on relative length of the weir $\delta / H$.

Table 3

Comparison of experimental discharge coefficients of $\mathrm{BCW} \boldsymbol{m}_{1}$ and $m_{2}$ with values according to Kumin's data $m_{K}$ (Rekomendatsii, 1974) and Hager's results $m_{H}$ (Hager \& Schwalt, 1994)

\begin{tabular}{|c|c|c|c|c|c|c|}
\hline \multirow{2}{*}{$P / H$} & \multicolumn{3}{|c|}{$\delta_{1}=10 \mathrm{~cm}$} & \multicolumn{3}{c|}{$\delta_{2}=20 \mathrm{~cm}$} \\
\cline { 2 - 7 } & $\delta / H$ & $m_{1} / m_{K}$ & $m_{1} / m_{H}$ & $\delta / H$ & $m_{2} / m_{K}$ & $m_{2} / m_{H}$ \\
\hline 5 & 10 & 1.014 & 1.014 & & & \\
\hline 4 & 8 & 1.016 & 1.020 & & & \\
\hline 3 & 6 & 1.017 & 1.028 & & & \\
\hline 2.5 & 5 & 1.017 & 1.033 & 10 & 0.959 & 0.974 \\
\hline 2 & 4 & 1.017 & 1.038 & 8 & 0.967 & 0.988 \\
\hline 1 & 2 & 1.010 & 1.041 & 4 & 0.986 & 1.032 \\
\hline 0.5 & & & & 2 & 1.002 & 1.063 \\
\hline
\end{tabular}

\section{Conclusions}

Experimental results indicate that the discharge coefficient of broad-crested weirs (BCW) depends on both the height and the length of the weir. The power law dependences (8) and (9) for rectangular sharp-edged BCW with vertical inlet and outlet walls with ratios of length of weir and height of weir $\delta / P=2$ and $\delta / P=4$ are obtained. To find a universal dependence $m=f(P / H, \delta / H)$ it is necessary to generalize the results for $\mathrm{BCW}$, with other length to height ratios.

\section{References}

Azimi, A. H., Rajaratnam, N., Zhu, D. Z. (2013). Discharge characteristics of weirs of finite crest length with upstream and downstream ramps. Journal of Irrigation and Drainage Engineering, 139(1), 75-83.

Badr, K., Mowla, D. (2014). Development of rectangular broad-crested weirs for flow characteristics and discharge measurement. KSCE Journal of Civil Engineering, 19(1), 136-141. DOI: 10.1007/s12205-012-0433-z 
Bolshakov, V. A. (1984) Spravochnyk po gidravlike. Kyiv, Vyshcha shkola, 343 pp. (in Russian).

Hager, W. H., Schwalt, M. (1994). Broad-crested weir. Journal of Irrigation and Drainage Engineering, 120(1), 13-26. doi.org/10.1061/(ASCE)0733-9437(1994)120:1(13)

Govinda Rao, N. S., Muralidhar, D. (1963). Discharge characteristics of weirs of finite-crest length. La Houille Blanche, 5, 537-545. doi.org/10.1051/lhb/1963036

Guven, A., Hassan, M., Sabir, S. (2013). Experimental investigation on discharge coefficient for a combined broad crested weir-box culvert structure. Journal of Hydrology, 500, 97-103. doi.org/10.1016/j.jhydrol.2013.07.021

Jalil, S. A., Ibrahim, S. S., Jafer, R. A. (2014). Surface roughness effects on discharge coefficient of broad crested weir. Research Journal of Applied Sciences, Engineering and Technology, 7(24), 5227-5233. DOI: 10.19026/rjaset.7.918

Konstantinov, Yu. K., Hizha, O. O. (2006). Inzhenerna hidravlika. Kyiv, Slovo, 432 pp. (in Ukrainian).

Kulkarni, K. H., Hinge, G. A. (2020). Experimental study for measuring discharge through compound broad crested weir. Flow Measurement and Instrumentation, 75, 101803. doi.org/10.1016/j.flowmeasinst.2020.101803

Rekomendatsii po gidravlicheskomu raschetu vodoslivov. Ch. I. Priamye vodoslivy. Leningrad, Energia, 1974, 58 pp. (in Russian).

Rohalevych, Yu. P. (2010). Hidravlika. Kyiv. Vyshcha shkola. 431 pp. (in Ukrainian).

Salmasi, F., Poorescandar, S., Dalir, A. H., Zadeh, D. F. (2011). Discharge relations for rectangular broadcrested weirs. Tarim Bilimleri Dergisi, 17(4), 324-336.

Sturm, T. W. (2001). Open Channel Hydraulic. McGraw-Hill Series in Water Resources and Environmental Engineering, 500.

Zachoval, Z., Knéblová, M., Roušar, L., Rumann, J., Šulc, J. (2014). Discharge coefficient of a rectangular sharp-edged broad-crested weir. Journal of Hydrology and Hydromechanics, 62(2), 145-149. DOI: 10.2478/johh2014-0014

Zhuk, V., Matlai, I., Popadiuk, I., Vovk, L. (2020). Discharge coefficient of broad-crested weirs as function of the relative weir length and height for weirs with large length to head ratios. Theoretical and scientific foundations of engineering: collective monograph. International Science Group. Boston, Primedia eLaunch, 96-101. (in Ukrainian). DOI : 10.46299/isg.2020.MONO.TECH.II

В. М. Жук, І. І. Матлай, І. Ю. Попадюк, Л. І. Вовк, В. А. Регуш Національний університет “Львівська політехніка”, кафедра гідротехніки та водної інженерії

\section{КОЕФНЦЕНТ ВИТРАТИ ВОДОЗЛИВУ 3 ШИРОКИМ ПОРОГОМ ЯК ФУНКЦІЯ БЕЗРОЗМІРНОЇ ВИСОТИ ПОРОГУ ДЛЯ ВОДОЗЛИВІВ РІЗНОЇ ШИРИНИ}

(ㄷ Жук В. М., Матлай I. І., Попадюк I. Ю., Вовк Л. І., Регуши В. А., 2020

Водозливи з широким порогом (ВШП) часто використовують у гідротехнічному будівництві та у водному господарстві. Найскладнішим для визначення фактором, що впливає на пропускну здатність ВШП, є його коефіцієнт витрати. В українській інженерній практиці коефіцієнт витрати ВШП визначають як функцію відносної висоти водозливної стінки, тоді як найпоширеніші європейські методики - як функцію відносної ширини порогу. У роботі отримано експериментальні залежності коефіцієнта витрати ВШП прямокутного профілю з вертикальними вхідною та вихідною гранями без заокруглення ребер для відношення ширини порогу та висоти стінки $\delta / P=2 ; 4$. Порівняння отриманих результатів зі значеннями коефіцієнта витрати аналогічних ВШП за методами Куміна та Хагера вказує на те, що цей коефіцієнт залежить і від висоти стінки, і від ширини порогу. Отримано відповідні емпіричні степеневі залежності. За однакових значень відносної висоти порогу коефіцієнт витрати для ВШП зі співвідношенням $\delta / P=4 \epsilon$ значимо менший, ніж для водозливу з $\delta / P=2$, що може бути пояснено суттєвішим впливом опору тертя для водозливу з більшою шириною порогу.

Ключові слова: водозлив 3 широким порогом, коефіщієнт витрати, відносна ширина порогу, відносна висота порогу. 